\title{
SIKAP BURUH TANI DI KECAMATAN PGL BDG MENGHADAPI ANJURAN STAY AT HOME
}

\author{
Deni Sutisna $^{1}$, Arif Widodo ${ }^{2}$, Muhammad Sobri $^{3}$, Mohammad Archi Maulyda $^{4}$, Nursaptini $^{5}$ \\ ${ }^{1}$ Program Studi Guru Sekolah Dasar, Fakultas Keguruan dan Ilmu Pendidikan, Universitas Mataram \\ Email: denisutisna@unram.ac.id \\ ${ }^{2}$ Program Studi Guru Sekolah Dasar, Fakultas Keguruan dan Ilmu Pendidikan, Universitas Mataram \\ Email: arifwidodo@unram.ac.id \\ ${ }^{3}$ Program Studi Guru Sekolah Dasar, Fakultas Keguruan dan Ilmu Pendidikan, Universitas Mataram \\ Email: muhammad.sobri@unram.ac.id \\ ${ }^{4}$ Program Studi Guru Sekolah Dasar, Fakultas Keguruan dan Ilmu Pendidikan, Universitas Mataram \\ Email: archimaulyda@unram.ac.id \\ ${ }^{5}$ Program Studi Guru Sekolah Dasar, Fakultas Keguruan dan Ilmu Pendidikan, Universitas Mataram \\ Email: nursaptini@unram.ac.id
}

\begin{abstract}
This study aims to examine the problems of various community behaviors in facing the threat of COVID-19, especially of farmworkers on the PGL sub-district, Bdg district. The basic reason for this research is that in the midst of the government's great efforts to suppress the spread of this virus by limiting community activities, both social distancing and suggestions to stay at home in various areas, the people of PGL sub-district, especially farmers and farm laborers, are still carrying out their activities. like before the COVID-19 pandemic. The descriptive method is used in this research. Observations were made with interview techniques and documentation because they were very appropriate for studying descriptive social problems such as this research. The reasons for farmers and farm laborers to continue their activities are: First, farm workers in PGL think that the COVID-19 pandemic will not hit their area, they believe they will remain healthy because of their work patterns that are outdoors and exposed to direct sunlight. The two economic factors and difficulties in fulfilling the necessities of life, the third is the lack of public awareness farmworkers about the dangers of COVID-19.
\end{abstract}

Keywords: pandemic, COVID-19, social distancing, labor

\begin{abstract}
ABSTRAK
Penelitian ini bertujuan untuk mengaji permasalahan tentang berbagai perilaku masyarakat dalam menghadapi ancaman COVID-19 terutama masyarakat kalangan buruh tani yang berada di kawasan kecamatan PGL kabupaten Bdg. Alasan mendasar dari penelitian ini adalah di tengah usaha pemerintah yang begitu besar dalam upaya menekan penyebaran virus ini dengan membatasi aktivitas masyarakat baik social distancing ataupun anjuran untuk stay at home di berbagai wilayah, tetapi masyarakat kecamatan PGL khususnya pada kalangan petani dan buruh tani masih menjalankan aktivitasnya seperti sebelum terjadi pandemi COVID-19. Metode deskriptif digunakan dalam penelitian ini. Pengamatan dilakukan dengan teknik wawancara, dan dokumentasi karena sangat tepat untuk mengkaji permasalahan sosial yang bersifat deskripsi seperti penelitian ini. Alasan para buruh tani tetap beraktivitas adalah: Pertama, buruh tani di PGL beranggapan pandemik COVID-19 tidak akan melanda wilayahnya, mereka berkeyakinan tetap sehat karena pola kerja mereka yang berada di luar ruangan dan terkena sinar matahari langsung. Kedua, faktor ekonomi dan kesulitan dalam pemenuhan kebutuhan hidup; ketiga, kurangnya kesadaran masyarakat kalangan buruh tani akan bahaya dari COVID-19.
\end{abstract}

Kata kunci : pandemic, COVID-19, social distancing, buruh

\section{PENDAHULUAN \\ Latar Belakang}

Buruh adalah sebutan untuk seseorang yang bekerja dan memiliki pekerjaan. Undang-undang Republik Indonesia Nomor 13 Tahun 2003 Tentang Ketenagakerjaan BAB 1 pasal 1 ayat 2 menyebutkan bahwa tenaga kerja adalah setiap orang yang mampu melakukan pekerjaan guna menghasilkan barang dan/atau jasa baik untuk memenuhi kebutuhan sendiri maupun untuk masyarakat. Dilanjutkan pada ayat 3 bahwa pekerja/buruh adalah setiap orang yang bekerja 
dengan menerima upah atau imbalan dalam bentuk lain. Secara bahasa buruh merupakan sebutan untuk seseorang yang bekerja dan diberi upah seperti halnya pegawai, pekerja, dan karyawan (Waridah \& Suzana, 2014).

Menurut jenis dan tempat pekerjaannya buruh dibedakan menjadi pabrik, buruh harian lepas, buruh musiman, buruh kasar, dan buruh tani. Seperti yang dikatakan oleh Wahyu, Suzana, dan Waridah (2013) bahwa buruh pabrik adalah orang yang bekerja pada sektor industri atau pabrik dengak skala industri yang cukup besar. Buruh musiman adalah buruh yang bekerja hanya pada waktu-waktu tertentu. Buruh harian lepas adalah pegawai yang bekerja dan dibayar sesuai dengan kedatangan bekerja. Buruh tani adalah pegawai yang bekerja di sektor pertanian baik di kebun, di ladang atau di sawah.

Makna buruh adalah sama yaitu pegawai atau pekerja, akan tetapi makna yang berbeda melekat pada profesi buruh tani. Identik dengan gaji yang kecil, beban kerja yang berat, serta tidak diperlukan keahlian yang sulit menjadikan profesi sebagai buruh tani menempati status sosial yang rendah dalam strata ekonomi bahkan tidak jarang orang yang memandang rendah kepada profesi tersebut. Sadikin dan Samandawa (2007) mengatakan bahwa buruh tani dianggap faktor paling lemah dan paling rendah dalam Industri pertanian di antara pemilik lahan, pemilik modal, dan teknologi pertanian. Selain itu buruh tani identik dengan kemiskinan. Bansal, Macwan, Devi, dan Jadav (2016) mengatakan bahwa buruh pertanian merupakan kelas yang paling diabaikan dan tertekan dalam struktur pedesaan karena standar kehidupan mereka yang rendah, oleh karena profesi menjadi buruh tani adalah profesi yang tidak didambakan oleh setiap orang.

PGL merupakan daerah dataran tinggi yang terletak di ujung paling selatan Bdg. Kontur wilayah perbukitan dengan suhu yang dingin dan tanah yang subur menjadikan daerah PGL menjadi daerah pertanian sebagai daerah penghasil sayuran terutama kentang, kol, sawi, wortel, tomat, cabai dan sebagainya. Selain itu PGL juga terkenal dengan perkebunan teh yang cukup luas serta sentra koperasi susu sapi terbesar di Indonesia. Meski terkenal sebagai daerah yang subur makmur, akan tetapi tidak semua masyarakatnya hidup berkecukupan. Pertanian yang menjadi komoditas utama daerah PGL hanya bisa dinikmati oleh sebagian kecil masyarakatnya saja dan yang lainnya hanya bekerja sebagai buruh tani.

Seperti yang telah dibahas pada paragraf sebelumnya bahwa penghasilan sebagai buruh harian lepas itu sangat rendah dan tanpa adanya tunjangan lainnya. Sebagai contoh saja mayoritas pekerja buruh tani di PGL berkisar antara Rp20.000,00-25.000,00/hari untuk perempuan dan Rp25.000,00-Rp35.000,00/hari untuk laki-laki. Perbedaan tersebut didasarkan atas perbedaan kemampuan bekerja yang dianggap bahwa laki-laki lebih memiliki tenaga lebih besar dibandingkan dengan perempuan meskipun pada pekerjaan yang sama. Dengan penghasilan sebesar itu masyarakat kalangan buruh harus bisa bertahan dan mengatur sedemikian rupa agar kebutuhan hidupnya bisa terpenuhi. Misalnya, seorang ayah dengan menanggung istri dan 2 anaknya dan memiliki penghasilan Rp30.000,00 per hari, meski dapat memenuhi untuk makan, akan tetapi belum memenuhi kepada standar hidup layak (Khomsan et al., 2015).

Bukan hanya di Indonesia, permasalahan buruh tani juga terjadi di negara lain bahkan lebih parah karena terjadi diskriminasi dan kesenjangan sosial seperti hasil penelitian dari Sefat-ezerin, Takashino, \& Fuyuki (2019) di Banglades dan Pannilage (2017) di Srilangka yang mengungkap akses pekerjaan sebagai buruh tani sebagian besar dimiliki oleh pria. Sekalipun kalangan wanita dapat bekerja pada sektor tersebut, terjadi diskriminasi dan kesenjangan dalam hal upah, sehingga kesulitan ekonomi kalangan buruh tani semakin terasa. Selain itu lebih parah 
terjadi di Afrika, di mana sering terjadi kelaparan dan rendahnya gizi dan ketahanan pangan pada kalangan masyarakat buruh pertanian (Devereux \& Tavener-Smith, 2019) dan Claasen \& Lemke (2019) yang mengemukakan bahwa "Pekerja pertanian yang di pekerjakan di pertanian komersial adalah di antara kelompok populasi yang paling miskin dan paling rawan pangan di Afrika Selatan"

Di tengah kesulitan dan kemiskinan yang terus membelenggu buruh tani, dunia dikejutkan dengan pandemic COVID-19 yang menyebabkan krisis kesehatan global. Cepatnya penyebaran yang timbulkan menyebabkan banyak negara terinfeksi sehingga mempengaruhi stabilitas negara dalam bidang keamanan, pendidikan, kesehatan dan tentunya perekonomian. Berbagai cara yang dilakukan oleh negara-negara yang terinfeksi virus tersebut sebagai upaya dalam menekan penyebaran dari pandemik tersebut. Indonesia sebagai negara yang terinfeksi virus tersebut berupaya untuk menekan penyebaran COVID-19. Meski hingga bulan Juni 2020 angka terinfeksi masih bertambah akan tetapi berbagai macam skenario telah diterapkan sebagai usaha dalam menanggulangi pandemik virus COVID-19 seperti pembatasan sosial, anjuran untuk tetap berdiam diri di rumah, pembatasan sosial berskala besar hingga larangan mudik ke luar daerah untuk seluruh masyarakat.

Meski program pemerintah tersebut bertujuan untuk kemaslahatan rakyat, akan tetapi tidak semua warga menyambut baik dan mampu menjalankan kebijakan serta anjuran-anjuran yang telah dikeluarkan oleh pemerintah. Masalah dasarnya klasik sebetulnya, yaitu permasalahan kebutuhan hidup yang tidak bisa di tangguhkan. Bagi masyarakat yang berpenghasilan cukup atau memiliki usaha, atau bagi mereka yang bekerja sebagai abdi negara yang kehidupannya sudah dijamin oleh pemerintah akan sangat mudah untuk menjalankan anjuran tersebut tetapi untuk kalangan miskin yang tidak memiliki penghasilan tetap atau sebagai buruh harian lepas seperti buruh bangunan, buruh perkebunan dan buruh tani akan sangat kesulitan jika harus berhenti beraktivitas. Seperti halnya yang terjadi pada kalangan masyarakat yang berprofesi sebagai buruh tani di Kecamatan PGL meskipun pemerintah mengeluarkan anjuran stay at home mereka masih beraktivitas seperti biasa dan bekerja sebagai buruh tani.

Pemerintah selalu mensosialisasikan bahaya COVID-19. Sosialisasi tersebut direalisasikan melalui pemerintah daerah Provinsi Jawa Barat, pada tingkat kabupaten, kecamatan hingga pemerintahan desa. Anjuran seperti stay at home dan selalu menjaga jarak serta yang lainnya telah direalisasikan, akan tetapi berdasarkan praduga sebagian besar buruh tani bersikap seolaholah tidak mempedulikan anjuran-anjuran tersebut.

Sikap merupakan keadaan internal yang mempengaruhi respon pribadi terhadap orang, benda atau peristiwa (Gosong, 2018). Berkaitan dengan itu sikap merupakan hak asasi yang dimiliki oleh setiap orang. Oleh karena itu seseorang bebas menunjukkan respon terhadap apapun selama hal tersebut tidak melanggar hak orang lain dan tidak melanggar hukum. Jelas memang bahwa anjuran stay at home dan pembatasan sosial ditujukan agar penyebaran virus COVID-19 dapat segera tertangani. Akan tetapi permasalahan sikap kalangan buruh tani yang tetap melakukan aktivitas pekerjaannya dikhawatirkan akan menjadi peluang dalam penyebaran COVID-19. Meskipun pemerintah sudah mengatur sedemikian rupa terkait anjuran stay at home dan pembatasan sosial akan tetapi sanksi yang diberikan belum sepenuhnya di terapkan, sehingga hal tersebut secara tidak langsung memberikan peluang bagi sebagian masyarakat untuk tidak melaksanakan anjuran pemerintah seperti yang dilakukan oleh kalangan buruh tani di Kecamatan PGL. 
Sikap yang diambil oleh kalangan buruh tani disinyalir akibat ketidakmampuan mereka untuk memenuhi kebutuhan hidup jika berdiam diri di rumah. Mereka mendapatkan upah jika mereka bekerja, dan itupun mereka cukup-cukupkan untuk memenuhi kebutuhan hidup. Oleh karena itu, penghasilan yang pas-pasan menjerat mereka tergolong kepada keluarga pra sejahtera atau miskin karena tidak dapat memenuhi standar hidup layak (BKKBN, 2011). Telah banyak penelitian tentang kemiskinan yang terjadi pada kalangan buruh. Seperti hasil penelitian dari Puspitawati, Putri, Titipani, dan Khasanah (2019) bahwa sebagian besar penduduk Indonesia yang tergolong dalam masyarakat miskin adalah masyarakat yang bertempat tinggal di daerah pedesaan dengan mata pencaharian sebagai petani dan buruh tani. Kesulitan ekonomi dialami oleh buruh tani dikarenakan upah yang diterimanya tidak menentu sehingga mereka tergolong pada masyarakat miskin. Selanjutnya penelitian Anwar dan Setiawan (2018) yang menemukan bahwa sebagian kecil dari kalangan buruh berpenghasilan sedang, sementara dilihat dari kesejahteraannya mereka masih berada pada posisi rendah. Begitu pula penelitian Syakirotin dan Charina (2020) bahwa kondisi ekonomi yang rendah memaksa kalangan wanita untuk berusaha membantu perekonomian keluarga dengan bekerja sebagai buruh tani, hal tersebut dilakukan karena tidak memiliki keahlian lain disebabkan oleh rendahnya tingkat pendidikan masyarakat sehingga tidak ada pilihan lain selain pekerjaan tersebut (Setiawan, 2017).

Berkaitan dengan permasalahan di atas maka penelitian ini bertujuan untuk mengkaji dan menganalisis tentang bagaimana sikap masyarakat, khususnya kalangan buruh tani yang berada di kawasan Kecamatan PGL Kabupaten Bdg dalam menyikapi anjuran pemerintah untuk tetap berdiam diri di rumah (stay at home dan social distancing) di tengah merebaknya COVID-19 dan faktor yang mempengaruhinya.

\section{Rumusan Masalah}

Berdasarkan latar belakang di atas, maka yang menjadi rumusan masalah adalah "Bagaimana para buruh tani di Kecamatan PGL dalam menyikapi anjuran pemerintah tentang stay at home dan faktor apa saja yang mempengaruhinya?"

\section{METODE PENELITIAN}

Penelitian ini digali dengan menggunakan metode kualitatif deskriptif. Wawancara dan observasi dijadikan teknik pengambilan data mengingat dengan teknik tersebut kita bisa lebih akurat dalam menggali data sehingga didapatkan data yang objektif (Moleong, 2005). Subjek penelitian adalah masyarakat yang bermata pencaharian sebagai buruh tani yang tersebar di seluruh desa di Kecamatan PGL yang berjumlah 24.353. Observasi dilakukan ke berbagai daerah di Pengalengan. Hasil observasi menunjukkan kesamaan pola kerja seperti pengaturan jam kerja, sistem pemberian upah kerja dan bonus atau tunjangan yang didapat. Oleh karena itu dapat ditarik kesimpulan bahwa para buruh tani mengalami kesulitan yang sama yaitu tingkat kesejahteraan yang rendah. Dengan alasan demikian sehingga metode yang digunakan adalah observasi ditambah dengan wawancara dengan beberapa orang buruh tani dan pemilik lahan sekaligus pemilik modal (petani yang memiliki pekerja). Setelah itu data didapat dan diolah dengan cara direduksi , disajikan, dan diverifikasi (Sugiono, 2013).

\section{HASIL DAN PEMBAHASAN}

Penelitian ini berusaha untuk mengungkap fenomena sosial tentang sikap masyarakat khususnya kalangan buruh tani dalam menjalani kehidupan sehari-hari di tengah anjuran pemerintah tentang stay at home atau anjuran tetap berdiam diri di rumah. Data yang diperoleh merupakan hasil observasi dan wawancara. Secara rinci hasil penelitian bisa dilihat pada bahasan ini. Pada dasarnya ada ataupun tidak ada COVID-19, para buruh tani tetap melaksanakan kegiatan 
kesehariannya seperti biasa. Dalam hal ini mereka masih bekerja ke kebun seperti biasanya. Ada beberapa alasan yang menyebabkan mereka masih bekerja dan seolah-olah tidak takut dengan pandemik COVID-19 yang tengah melanda berdasarkan hasil wawancara.

Pertama, Timbulnya pemahaman masyarakat bahwa pandemik tersebut terjadi di kota-kota besar. Hal tersebut sesuai dengan kutipan wawancara tentang seberapa besar rasa takut mereka akan pandemik COVID-19. Kutipan wawancaranya seperti yang tertulis di bawah ini "ah jang da di dieumah di kampung urang kampung jauh ti kota jadi nukaritu mah moal narepi kadieu, terus da didieumah di daramelna oge kakebon ungal dinten jadi damelna ngaluarken kesang pasti lewih sehat da ka olah ragaken tiap dinten terus pan kapoe damelna oge, pan saur dina tv lamu anus ok moyan korona na ge bakal sieunen, jadi bisa uae di dieumah, ulah sieun kunu karitu" jika diartikan kira-kira seperti ini "Karena ini di perkampungan dan cukup jauh dari kota jadi virus tersebut tidak akan sampai kesini, selain itu pola pekerjaan menjadi buruh tani banyak mengeluarkan keringat sehingga tubuh akan lebih sehat dan bugar, satu hal lagi pola kerja buruh di bawah sinar matahari sehingga seperti diberitakan di TV virus akan mati jika terkena cahaya matahari". Berbeda dengan informan yang sebelumnya, informan kedua malah menyatakan takut akan virus COVID-19 akan tetapi kembali lagi bahwa beliau menganggap daerahnya tidak akan terjangkit oleh virus tersebut dan pola kerja yang sama juga sehingga beliau yakin akan terus baik-baik saja meskipun beraktivitas seperti biasa. Ada beberapa alasan mengapa mereka berpandangan seperti itu, di antaranya: 1) daerah PGL sampai bulan Juli masih dinyatakan sebagai zona kuning di mana pada saat itu belum ada yang dinyatakan positif terkena virus COVID-19; 2) mereka merasa tidak takut karena belum pernah melihat secara langsung tetangga atau saudaranya yang terkena COVID-19; 3) menganggap bahwa daerahnya tidak akan terkena virus COVID-19; 4) mereka beranggapan bahwa mereka akan kuat menghadapi COVID-19 karena mereka bekerja di bawah sinar matahari langsung dan bekerja dengan fisik yang banyak dan bekerja mengeluarkan keringat sehingga fisik kita terlatih dan memiliki imun yang tinggi. Selain itu mereka beranggapan jika terkena sinar matahari secara langsung maka virusnya akan mati seperti yang banyak diberitakan di TV.

Kedua, mengapa mereka para buruh tani seolah-olah tidak mengindahkan bahaya COVID-19 dan anjuran pemerintah tentang stay at home dikarenakan alasan ekonomi. Kutipan wawancara menjelaskan bahwa sebagian besar para buruh tani tidak memiliki pekerjaan lain selain itu. Artinya buruh tani menjadi penghasilan utama. Meskipun ada yang sampingan saja tetapi profesi orang tersebut sebagai buruh serabutan seperti buruh bangunan, buruh perkebunan dan jika tidak ada pekerjaan mereka menjadi buruh pertanian juga. Atau misalkan seorang yang suaminya seorang peternak sapi perah mungkin saja istrinya menjadi buruh tani. Dari ulasan diatas dapat diartikan bahwa yang menjadi pekerja sebagai buruh tani merupakan kalangan dengan ekonomi kecil dan memang tergolong orang dengan tingkat kesejahteraannya rendah. Hal tersebut sangat masuk akal karena upah perharinya itu hanya berkisar antara Rp20.000,00-25.000,00/hari untuk perempuan dan Rp25.000,00-Rp35.000,00/hari untuk laki-laki. Jika dalam satu keluarga suami dan istrinya bekerja mungkin bisa mendapatkan Rp45.000,00-60.000,00/hari akan tetapi jika hanya suaminya saja yang bekerja. Sistem pengupahan mereka juga sama halnya seperti buruh harian lepas, di mana mereka akan mendapatkan upah jika mereka bekerja. Tidak ada istilah cuti, izin, atau sakit. Mereka diupah jika mereka bekerja, tidak ada tunjangan dan toleransi kecuali saat hari raya idul fitri itu pun dengan jumlah nominal tergantung keridhoan majikannya, tidak ada standar yang jelas. Kesulitan ekonomi yang mereka alami akan bertambah mana datang musim kemarau, secara otomatis sebagian besar dari mereka yang tidak bekerja dikarenakan kekeringan lahan terkecuali bagi mereka yang bekerja pada petani yang lahan pertaniannya dekat dengan sungai dan sumber mata air. Itupun jika ketersediaan airnya masih ada, oleh karena itu 
selama masih ada pekerjaan mereka tidak akan berhenti. Intinya selama masih ada kesempatan untuk bekerja mereka akan terus bekerja. Data tersebut berdasarkan hasil wawancara, observasi juga. Hal tersebut dibenarkan oleh salah seorang petani yang cukup banyak memiliki pekerja.

Ketiga, kurangnya kesadaran mereka akan bahaya atau ancaman covid-19. Pada dasarnya pemerintah mulai pemerintah pusat, daerah, kabupaten, kecamatan serta desa sudah berupaya untuk memberikan informasi dan edukasi masyarakat akan bahaya yang ditimbulkan dari pandemik tersebut.

Pada dasarnya yang menjadi penyebab mengapa kalangan buruh tani tidak bisa mengikuti anjuran pemerintah tentang stay at home atau anjuran tentang tetap berdiam diri di rumah karena faktor ekonomi atau kesulitan dalam memenuhi kebutuhan hidup terutama kebutuhan pokok. Buruh tani memiliki penghasilan yang rendah sehingga hanya cukup memenuhi kebutuhan hidupnya, itupun dengan cara berhemat. Para buruh tani hanya mengandalkan tenaga sehingga tidak ada kesempatan bagi mereka dalam negosiasi upah (Astuti, 2016) karena secara sosiologis buruh tidak memiliki hubungan yang bebas bersama majikannya sehingga tidak ada kesempatan untuk negosiasi upah kerja (Syakirotin \& Charina, 2020). Para petani atau pemilik modal yang menentukan upahnya. Tidak ada standar minimal atau maksimal upah, semua tergantung kepada kebiasaan umum dari petani-petani yang lain. Belum lagi terjadi diskriminasi yang membedakan pola upah antara laki-laki dan perempuan. Dalam hal ini perempuan memiliki upah lebih rendah dibandingkan laki-laki, hal tersebut karena dalam dunia pertanian perempuan dianggap lemah dalam bekerja dibandingkan laki-laki (Sefat-e-zerin et al., 2019).

Ketakutan para buruh tani di Kecamatan PGL akan tidak terpenuhinya kebutuhan pokok terutama sandang lebih besar dibandingkan ketakutan mereka akan bahaya COVID-19. Kesulitan hidup, keterbatasan ekonomi, dan kurangnya pemahaman menjadi faktor dominan yang mempengaruhi sikap masyarakat tersebut. Dalam hal ini pemerintah harus lebih memperhatikan kondisi dan kesulitan yang sedang di hadapi oleh masyarakat terutama kalangan berpenghasilan rendah seperti buruh tani. Bukan hanya sekedar bantuan langsung berupa materi akan tetapi yang lebih diutamakan adalah solusi agar masyarakat kecil bisa lebih mandiri dan bisa meningkat kesejahteraannya baik dengan jalan pelatihan ataupun pendidikan.

Sebagian besar dari kalangan buruh tani di Kecamatan PGL memiliki pendidikan yang rendah, jarang di antara mereka yang lulus SMP apalagi SMA. Rata-rata dari mereka lulusan SD bahkan ada yang tidak pernah sekolah. Oleh karena itu pola pikir mereka sederhana, bagaimana sekarang bisa makan, dan bagaimana besok bisa bertahan. Kondisi tersebut tidak memberikan banyak pilihan atau kesempatan bagi mereka dalam menentukan mata pencaharian, oleh karena itu akses para buruh tani ke sektor pekerjaan lainnya sangat terbatas (Pannilage, 2017).

Pemerintah pada dasarnya telah memperbaiki sistem pendidikan di Indonesia dan selalu mengampanyekan tentang wajib belajar 12 tahun. Hal tersebut ditujukan untuk meningkatkan kualitas hidup masyarakat. Sejalan dengan tujuan pendidikan nasional yang tertuang dalam Undang Undang Republik Indonesia Nomor 2 Tahun 1989 Tentang Sistem Pendidikan Nasional bab II pasal 4 yang berbunyi "Pendidikan nasional bertujuan mencerdaskan kehidupan bangsa dan mengembangkan manusia Indonesia seutuhnya, yaitu manusia yang beriman dan bertaqwa terhadap Tuhan Yang Maha Esa dan berbudi pekerti luhur, memiliki pengetahuan dan keterampilan, kesehatan jasmani dan rohani, kepribadian yang mantap dan mandiri serta rasa tanggung jawab kemasyarakatan dan kebangsaan". Hal tersebut jelas bahwa pendidikan sangat berperan dalam meningkatkan pola pikir masyarakat agar masyarakat lebih mantap untuk 
bertindak, bersikap dan menentukan keputusan tinggal bagaimana realisasi dan implementasi dari tujuan tersebut.

Sistem pendidikan disusun berdasarkan asas manfaat dan keperluan yang dihadapi masyarakat. Jika sistem pendidikan sudah mampu diimplementasikan dengan baik, maka seharusnya permasalahan kesejahteraan sosial sudah dapat terselesaikan. Sejalan dengan hasil penelitian dari Aini, Isnaini, Sukamti, \& Amalia (2018) bahwa pendidikan erat kaitannya dengan kesejahteraan masyarakat, orang yang berpendidikan tinggi lebih banyak peluang untuk mendapatkan kesempatan dalam pekerjaan sehingga kesejahteraannya pun akan meningkat. hal tersebut sejalan dengan penelitian dari Sulistyowati (2010) yang menyatakan bahwa pendidikan merupakan investsi baik jangka pendek ataupun jangka panjang dalam meningkatkan kesejahteraan masyarakat. Oleh karena itu pendidikan merupakan hal yang mutlak diperlukan demi meningkatnya kesejahteraan masyarakat

\section{KESIMPULAN DAN SARAN}

Garis merah yang ditarik menjadi kesimpulan dalam penelitian ini adalah: 1) masyarakat PGL yang berprofesi sebagai buruh tani menganggap bahwa pandemik COVID-19 tidak akan melanda PGL dan mereka berkeyakinan bahwa mereka akan tetap sehat karena pola kerja mereka yang berada di luar ruangan dan terkena sinar matahari langsung; 2) faktor ekonomi dan kesulitan dalam pemenuhan kebutuhan hidup terutama kebutuhan pokok menjadi alasan mengapa mereka tidak mengurangi aktivitas pekerjaan mereka. Bukan tidak ingin mengikuti anjuran pemerintah untuk tetap berdiam diri di rumah, akan tetapi kondisi profesi sebagai buruh tani memiliki pendapatan yang rendah sehingga mereka lebih takut tidak mendapatkan penghasilan dibandingkan dengan ancaman pandemik COVID-19; 3) kurangnya kesadaran masyarakat kalangan buruh tani akan bahaya dari COVID-19.

Oleh karena itu meskipun sosialisasi dan edukasi terus dilaksanakan oleh pemerintah, dan sumbangan baik secara langsung ataupun tidak langsung sudah berjalan akan tetapi masih diperlukan formula yang tepat agar masyarakat kecil bisa terus melanjutkan aktivitas hidupnya tanpa bayangan-bayangan menakutkan karena pandemik COVID-19

\section{Ucapan Terima Kasih (Acknowledgement)}

Ucapkan terima kasih kepada pihak-pihak yang telah membantu pada proses penelitian, terutama kepada masyarakat PGL, key-informant, dan lembaga pemerintahan Kecamatan PGL. Semoga hasil penelitian ini bisa dijadikan sumber rujukan untuk perbaikan pembangunan Kecamatan PGL, atau bisa dijadikan referensi penelitian lainya.

\section{REFERENSI}

Aini, E. N., Isnaini, I., Sukamti, S., \& Amalia, L. N. (2018). Pengaruh tingkat pendidikan terhadap tingkat kesejahteraan masyarakat di kelurahan kesatrian kota Malang. Technomedia Journal, 3(1), 58-72. https://doi.org/10.33050/tmj.v3i1.333

Anwar, K., \& Setiawan, H. (2018). Analisis perbandingan pendapatan buruh harian tetap dengan buruh harian lepas dan pengaruhnya terhadap kesejahteraan keluarga buruh perkebunan $\begin{array}{llllll}\text { kelapa sawit di } & \text { 73-81. }\end{array}$ https://doi.org/https://doi.org/10.29103/jepu.v1i2.864

Astuti, W. A. (2016). Hubungan kerja petani-buruh tani di pedesaan dan faktor yang mempengaruhinya. Forum Geografi, 7(1), 64. https://doi.org/10.23917/forgeo.v7i1.4798 
Bansal, R.K., Macwan, J., Devi, G, \& Jadav, K.S. (2016). Income, employment and consumption pattern of agricultural laborers in Central Gujarat. Indian Journal of Economics and Development, 12(1A).231-236. $\quad$ https://doi.org/http://dx.doi.org/10.5958/23220430.2016.00068.8

BKKBN. (2011). Batasan dan pemutakhiran data MDDK. Diambil 9 Mei 2020, dari BKKBN Pemutakhitan Data Keluarga website: http://aplikasi.bkkbn.go.id/mdk/BatasanMDK.aspx

Claasen, N., \& Lemke, S. (2019). Strong ties, weak actors? Social networks and food security among farm workers in South Africa. Food Security, 11(2), 417-430. https://doi.org/10.1007/s12571-019-00902-5

Devereux, S., \& Tavener-Smith, L. (2019). Seasonal food insecurity among farm workers in the Northern Cape, South Africa. MDPI JOurnals, 17(9), 15-35. https://doi.org/https://doi.org/10.3390/nu11071535

Gosong, D. (2018). Belajar dan pembelajar. Yogyakarta: CV Budi Utama.

Khomsan, A., Darmawan, A. H., Saharuddin, Alfiasari, Syarif, H., \& Sukarndar, D. (2015). Indikator kemiskinan dan mengklasifikasi orang miskin. Jakarta: Fakulatas Ekologi Manusia IPB bekerja sama dengan Pustaka Obor Indonesia.

Moleong, L. J. (2005). Metode penelitian kualitatif. Bandung: PT Remaja Rosdakarya.

Pannilage, U. (2017). A socio-economic analysis on the gender wage gap among agricultural laborers in rural Sri Lanka Upali Pannilage. American Scientific Research Journal for Engineering, Technology, and Sciences (ASRJETS), 338-350. https://doi.org/http://asrjetsjournal.org/ A

Puspitawati, H., Putri, A. C. J., Titipani, A., \& Khasanah, M. N. (2019). Kontribusi ekonomi perempuan, tekanan ekonomi dan kesejahteraan keluarga pada keluarga nelayan dan buruh tani bawang merah. Jurnal Ilmu Keluarga dan Konsumen, 12(2), 87-99. https://doi.org/10.24156/jikk.2019.12.2.87

Sadikin, \& Samandawai, S. (2007). Konflik keseharian di pedesaan Jawa. Bandung: AKATIGA.

Salinan Undang Undang Republik Indonesia Nomor 2 Tahun 1989 Tentang Sistem Pendidikan Nasional. Di akses pada tanggal 18-11-2020 https://luk.staff.ugm.ac.id/atur/UU21989Sisdiknas.pdf

Sefat-e-zerin, M., Takashino, N., \& Fuyuki, K. (2019). Challenges of women agricultural laborers in the northern part of Bangladesh. 6(10), 225-238. https://doi.org/https://doi.org/10.14738/assrj.610.7232

Setiawan, E. (2017). Konstruksi sosial pembagian kerja dan pengupahan buruh tani. YINYANG: Jurnal Studi Islam, Gender dan Anak, 12(1), 19-34. https://doi.org/10.24090/yinyang.v12i1.2017.pp19-34

Sugiono. (2013). Metode penelitian pendidikan (pendekatan kuantitatif, kualitatif, dan R\&D). Bandung: Alfabeta.

Sulistyowati, N. (2010). Dampak investasi pendidikan terhadap perekonomian dan kesejahteraan masyarakat kabupaten dan kota di Jawa Tengah. Pascasarjana Institut Pertanian Bogor.

Syakirotin, M., \& Charina, A. (2020). The level of family welfare of female farmworkers in the coffee production section at CV. Jurnal Ilmu Pertanian Indonesia, 25(1), 100-110. https://doi.org/10.18343/jipi.25.1.100

Wahyu, Suzana, \& Waridah, E. (2013). Kamus besar bahasa Indonesia. Bandung: Kawah Pustaka.

Waridah, E., \& Suzana. (2014). Kamus bahasa Indonesia. Bandung: Kawah Media. 